\title{
Education of persons with intellectual disabilities in India
}

\author{
L Govinda Rao, $\mathrm{PhD}^{(1)}$
}

Rao LG.

Education of persons with intellectual disabilities in India. Salud Publica Mex 2008;50 suppl 2:S205-S2I2.

\begin{abstract}
Historically in India, persons with disabilities enjoyed co-existence, though at different times, the treatment and attitudes were at variance. Out of all the types of disabilities, an intellectual disability poses greater challenges than the other types. The families of persons with intellectual disabilities do also have needs different from others, which cannot be segregated from the needs of children with intellectual disability. Specific legislations have been put in place to ensure empowerment of persons with disabilities. Through Rehabilitation Council of India, human resource development programs are standardized. The National Institute for the Mentally Handicapped has developed many service models and contributed toward human resource development and research. Many Non-Government Organizations have started special education and vocational training programs. National Trust, a statutory body, supports the individuals and families and seeks to protect those individuals having no parents. Sarva Shiksha Abhiyan (Education for All), has special focus on education of children with disabilities.Vocational training centres have an obligation to develop eco-centric and commercially viable jobs. As per the National Policy, the Government of India envisages that every child with a disability should have access to appropriate preschool, primary and secondary level education by 2020 .
\end{abstract}

Key words: persons with disabilities; intellectual disability; empowerment; human resource development; special education; vocational training; India
Rao LG.

Educación de las personas con discapacidad intelectual en India. Salud Publica Mex 2008;50 supl 2:S205-S2I 2.

\section{Resumen}

Históricamente en India las personas con discapacidades han disfrutado siempre de la coexistencia, si bien a veces el tratamiento y las actitudes podían contrastar. De entre todos los tipos de discapacidad, la intelectual es la que presenta los mayores desafíos. Las familias de las personas con discapacidad intelectual tienen asimismo necesidades distintas de las demás, inseparables de las necesidades de los niños con discapacidad intelectual. Se ha implementado legislación específica para asegurar el apoderamiento de las personas con discapacidades. Los programas de desarrollo de recursos humanos se normalizan a través del Consejo de Rehabilitación de India. El Instituto Nacional para los Discapacitados Mentales ha desarrollado diversos modelos de servicios y contribuido a la investigación y desarrollo de recursos humanos. Muchas Organizaciones No Gubernamentales han iniciado programas de educación especial y de entrenamiento vocacional. El Fideicomiso Nacional, una institución oficial, apoya a los individuos y a las familias y protege a los huérfanos. Sarva Shiksha Abhiyan (Educación para Todos), se enfoca particularmente en la educación de los niños con discapacidades. Los centros de entrenamiento vocacional tienen la obligación de crear trabajo ecocéntrico y comercialmente viable. En cuanto a la política nacional, el Gobierno de la India se propone que todo niño con discapacidad deberá tener acceso a la educación preescolar, primaria y secundaria para 2020.

Palabras clave: personas con discapacidades; discapacidad intelectual; apoderamiento; desarrollo de recursos humanos; educación especial; entrenamiento vocacional; India

(I) Lead Partner and Head, Medical Research \& Training and Disability, Byrraju Foundation. Andhra Pradesh, India. 
I ndia is one of the earliest known civilizations, covering an area of $3287263 \mathrm{sq} \mathrm{km}$, extending from the snow-covered Himalayan heights to the tropical rainforests of the south. At 60 years of Independence, with the programs based on the vision of the first Prime Minister to turn India into a technologically and industrially developed country, the country has now achieved multifaceted socio-economic progress. Today, having once been a food insecure country for very long, it has become self-sufficient in agricultural production and is presently the tenth industrialized country in the world and the sixth nation to have explored space.

\section{Historical perspective in India}

Historically, in India, persons with disabilities (PWD) enjoyed co-existence with the general mass, though at different times, the treatment and attitudes were at variance. In other words, they were never excluded from society by confinement to institutions. Rather, they lived with their families. As far as education was concerned, even the Gurukula Ashram promoted the basic educational principles of special education like ascertaining the abilities and needs of each pupil, individualization of teaching targets and methods to match the skills and interests and preparing them to meet the social expectations of their prospective interests.

In intellectual disability, unlike other disabilities, the history of special education has not been very encouraging. The first school for intellectual disability was established in 1940 as per the report of the expert group of the National Planning for the Mentally Handicapped held in New Delhi on 12-17 November 1979. After independence, there has been some growth of special education in our country and it has been seen that during 1960 and 1975, 81 schools were established. By 1979 , the number of special education centres was 150. With the establishment of the National Institute for the Mentally Handicapped, availability of trained personnel and suitable models of service made the growth of special schools for children with intellectual disability very significant.

\section{Intellectual disabilities - needs}

Persons with disabilities have been there since the time when human beings evolved and started forming their assemblage. Out of all the types of disabilities, an intellectual disability poses greater challenges than the other types do. Persons with intellectual disabilities have a condition of arrested or incomplete development of mind, which is especially characterized by sub-normal intelligence, thus partially or totally restricting the person's ability to perform certain activities in their life. This is owing to impairment in cognitive, emotional or behavioural endowment. One of the key abilities for human beings to lead an independent life is to take decisions independently, which persons with mental retardation are, unfortunately, not endowed with. Therefore they have special needs, which basically include activities for daily living (ADL); instrumental activities of daily living (IADL); reading, writing and arithmetic skills; extra curricular activities, namely sports and games, art and cultural activities; social activities; vocational and employment activities; independent living skills; and community integration; etc. Every activity of persons with mental retardation has a meaning in their life, which they have to acquire through individualized education plan supported by related services. viz. audiology services, counselling services, early identification and assessment of disabilities in children, medical services, occupational therapy, orientation and mobility services, parent counselling and training, physical therapy, psychological services, recreation, rehabilitation, school health services, social work services in schools, speech-language pathology services, and transportation.

The families of persons with mental retardation, particularly the parents and siblings, do also have needs different from others, which cannot be segregated from the needs of children with mental retardation, if our intention is to extend proper rehabilitation services. Some of the important family needs are: information about the condition of the child, management of the child, services available, vocational rehabilitation, marriage of the child, emotional needs, societal acceptance of the child, government benefits and legislation, relief of burden (financial and respite), etc. The needs of the families having a child with mental retardation are very complex and call for developing support programs for these families.

\section{Indian Constitution and legislation \& government initiatives}

India, being a signatory to the United Nations (UN) instruments, has undertaken the rehabilitation programmes on a massive scale. While recognizing the need to fulfil commitments as per the UN declarations and mandates, India being aware of its obligation under the Constitution of India, has introduced various programmes and schemes for the empowerment of persons with disabilities. Articles 15 and 41 afford protection to the rights of persons with disabilities. Disabled persons have been guaranteed the Fundamental Rights as available to other citizens of the country. These include equality of 
opportunity; non-discrimination; non-untouchability; no traffic in human beings; prohibition of employment of children; religious freedom; right to the language, script or culture; right to franchise; right to property; right to enforce fundamental rights; access to education in any educational institution, and the right to work.

The State has also the obligation to apply the Directive Principles of State Policy of securing a social order in promotion of the welfare of the people. The State Policy has to be directed toward minimizing inequalities, securing the right to an adequate means of livelihood and also ensure that the operation of the legal system promotes justice. Among many other provisions, the State also has the responsibility of promoting with special care the educational and economic interests of the weaker sections of the people including persons with disabilities.

The paradigm shift from the welfare and charity approach to rights based one towards the issues concerning persons with disabilities is encapsulated most effectively through the landmark enactment of the Persons with Disabilities (Equal Opportunities, Protection of Rights and Full Participation) Act, 1995. The Act establishes the responsibility on the appropriate Governments and society to ensure free education for persons with disabilities up to the age of 18 years, preference in employment in the public sector through the reservation of $3 \%$ of vacancies against identified posts and accessibility to buildings, roads, transport and other public services. The Act also prohibits discrimination in every sphere on the grounds of disability. ${ }^{1}$

This was followed in 1999 by the enactment of the National Trust for the Welfare of Persons with Autism, Cerebral Palsy, Mental Retardation and Multiple Disabilities Act. The objective of this enactment is to enable and empower persons with these disabilities to live as independently and as fully as possible within or close to the community to which they belong. It also addresses the needs of those persons who do not have family support and provides for their care and protection. ${ }^{2}$

\section{Education of persons with intellectual disabilities -some experiences}

It has been realized that education of persons with disabilities is very crucial for their development and living as independently as possible. Hence, it has also undergone great metamorphosis aiming at empowerment for independent living. Charity has given way to right as far as the education of persons with disabilities is concerned. Education has become a fundamental right of every child.

Equal opportunity is the bedrock of the growth of special education, which advocates not only ac- cess to education but also meaningful, appropriate and quality education adding value to the development of persons with disabilities. Special settings for the education of these children made them secluded from society and they were looked upon as a separate part of society. Concern regarding this arose in the pertinent welfare departments. Other government departments and the general population were not at all concerned about the education of these special children.

Evolving strategies to enlist the support of the Department of Human Resources Development and other developmental agencies has become a continual process for inclusion in India. Mainstreaming is one such concept for the practice of selectively placing students with disabilities in one or more 'regular' education classes. This approach presupposed that the student must fit in the school environment designed for regular children; thereby the equal opportunity principle has received a great blow of defeating the purpose. Then there came the concept of inclusion that expresses commitment to educate each child, to the maximum extent appropriate, in the school and classroom the student would otherwise attend. It involves bringing the support services to the child, rather than moving the child to the services, and requires only that the child benefit from being in the class, rather than having to keep up with the other students. This has further led to the concept of full inclusion in which all students, regardless of the handicapping condition or severity, will be in a regular class room full time. All services must be taken to the child in that setting.

These concepts have transformed from various philosophical frameworks, which cannot escape the practicality of limitations and constraints involved in implementation. Each of the systems of special education is interdependent, in which the severity of the disability plays a key role. For example, a special setting is surely needed if the condition of the child is severe or profound, which is most restrictive. As the disability condition moves towards mild in the continuum, the child's ability improves and he or she can come out of the restrictive environment and into open system. However, there are some factors that are irrespective of the condition of the disability, efforts of rehabilitation professionals, and Government support. One of these factors, which is very crucial for a successful inclusive education of children with disabilities, is a positive, favourable attitude of the community and teachers in the general stream, making available appropriate skills for a proper teaching process and making the school environment disabled friendly. Teacher readiness, school readiness, and community acceptance are the core aspects of educating children with disabilities. Continual 
consultations with and involvement of parents and family members is an integral part of the special education process.

\section{Current scenario}

The Government of India, has implemented the rehabilitation programmes on a massive scale. In a systematic way, the work started in the early 1980's has been instrumental in building capacities in terms of trained teachers, development of teaching and learning materials, models of context specific educational and therapeutic services, promotion of Non-Government organizations (NGOs), extensive coverage of persons with disabilities under the scheme of providing aids and appliances, and use of technology for improvement in education. The programmes to sensitise the community, government machineries, and other developmental agencies are very significant in the acceptance of and providing support to persons with disabilities. Convergence of various governmental schemes for the empowerment of persons with disabilities is another bold step initiated by the Government. It has also made a purposeful endeavour to include disability rehabilitation as an area of critical social development responsibility and accountability of the national planning process from the 8th Five Year Plan onwards. During the 10th Five Year Plan, the outlay will be 14541 million Rupees, and the process of the 11th Five Year Plan to commence from 2007 will focus on the early intervention, education, employment, aiming at a barrier free and inclusive society.

Education of children with disabilities was not lost from the sight of various commissions of Government of India. The Kothari Commission (1964-1966) observes that the coveted goal of Universalisation of Elementary Education (UEE) depends upon the extent of success in bringing special groups of children within the educational network. However, not much was attempted to increase the coverage of children with disabilities in the educational network, who constituted just $0.07 \%$ of the total children at the elementary stage. This has increased to $1 \%$ with the review of National Policy on Education (1992). An integration approach was largely adopted. Children with locomotive disabilities, low vision and blindness are enrolled in regular schools in larger numbers when compared to those with intellectual disability and hearing impairment. This is owing to the fact that children with intellectual disability require significant adaptation in the curriculum and children with hearing impairment require teachers trained specifically in effective communication with these children. Teacher preparation in special education is very essential. Integration is to support the children in the content and process of teaching besides physical adjustments and rearrangements. Education through the integration mode has been imparted to a large number of children with disabilities by both governmental and non-governmental agencies in the country.

Integrated Education for Disabled Children (IEDC) was introduced in 1974 initially by the Ministry of Welfare and later on handed over to the Ministry of Human Resource Development, Department of Education, which is being implemented in over 20000 schools in India covering over 120000 children with disabilities. IEDC has contributed significantly in incorporating the special needs inputs in the teacher education curriculum for primary and secondary teachers prepared by District Institutes of Education and Training. It has also contributed in large scale production of print and non-print material. During the 1987-1994 period UNICEF assisted Project Integrated Education for the Disabled (PIED) under NCERT (National Council of Educational Research \& Training) was taken up to provide education for all children with disabilities and to allow them and their families, neighbours and nondisabled children to interact in normal settings. It aimed to develop competencies in children with disabilities so as to provide a natural basis for adult life experiences in such a manner that they can perceive themselves as contributing members to socio-economic development of the society. Subsequently, the District Primary Education Programme was launched in 1994, in which 18000 regular teachers were trained to impart special education inputs to children with special needs. Janashala is another programme, which is a community school aiming to support ongoing efforts of the Government of India towards UEE with special focus on the problems of girls and underprivileged children.

In 1994, the Government of India launched the District Primary Education Programme (DPEP), a centrally sponsored scheme funded by the World Bank and other foreign agencies, which emphasized UEE through developmental management, a participatory process, and capacity building at all levels. DPEP covered IEDC as its component and adopted an area approach, in 18 states. Since UEE has not been achieved fully, the Government of India launched Sarva Shiksha Abhiyan (SSA - Education for All), which also made special provision for serving children with disabilities. It has set a target to provide useful and quality elementary education to all children in the 6-14 year age group by 2010, which promotes decentralized planning with full involvement of Panchayat Raj Institutions (PRIs). The programmes of SSA are as follows: 
- Early detection and identification

- Functional and formal assessment

- Educational placement

- Provision of aids and appliances

- Support services

- Teacher training

- Resource support

- Individualised education plan

- Parental training and community mobilisation

- Planning and management

- Strengthening of special schools

- Removal of architectural barriers

According to the Census of India, out of 21.9 million persons with disabilities 10.8 million persons are literate, constituting 49 per cent. The rate of literacy by residence is $44.4 \%$ for rural and $63.9 \%$ for urban population with disabilities. The number of persons with various disabilities according to the 2001 Census is shown on table I. ${ }^{3}$

According to the 2001 Census, the number of persons with visual disabilities made up almost half $(48.55 \%)$ of all persons with disabilities, whereas persons with hearing disabilities comprised the smallest category at 5.76 percent.

Most of the special schools are funded by Government of India. According to the study of Rao and Reddy, various services are available across these centres, as shown on table II.

Vocational Training and employment is a major area in the empowerment of persons with intellectual disabilities. The profile of vocational training and employment is mentioned in table III. ${ }^{5}$

Vocational training centres have an obligation to develop eco-centric and commercially viable jobs. In plain terms, after the vocational training, the person with intellectual disability has to earn to live indepen-

\section{Table I}

Persons With disabilities in India by type OF DISABILITY

\begin{tabular}{lccc} 
Type of disability & $\begin{array}{c}\text { Number } \\
\text { of persons (\%) }\end{array}$ & $\begin{array}{c}\text { \% of the total } \\
\text { population of India }\end{array}$ \\
Visual & 10634881 & $(48.55)$ & 1.03 \\
\hline Speech & 1640868 & $(7.49)$ & 0.16 \\
\hline Hearing & 1261722 & $(5.76)$ & 0.12 \\
\hline Movement & 6105477 & $(27.87)$ & 0.59 \\
\hline Mental & 2263821 & $(10.33)$ & 0.22 \\
\hline Total & 21906769 & $(100.00)$ & 2.13
\end{tabular}

Source: Census of India 200I dently as far as possible. A vocational training program that is not leading to livelihood programs needs to be discarded unless it helps in improving the generic skills. An appropriate vocational climate for persons with intellectual disabilities is essential for better results of the vocational training and job placement and ultimate employment for independent living. ${ }^{5}$

\section{Rehabilitation Council of India}

The Rehabilitation Council of India (RCI) was established under the RCI Act, 1992 with a key mandate to recognize and regulate rehabilitation education. As of now, RCI has recognised about 250 human resource development centres and 56 long-term professional courses where the special education programmes and other professional courses are conducted. Until now, RCI has registered more than 30000 professionals. $^{6}$

Table II

\section{Services aVAilable at SPECIAL SCHOOLS IN INDIA}

Facilities/services $\%$ of special schools

Residential 26

Prevocational + Vocational Training 60

Home based 32

Early Intervention 31

Sheltered workshops 13

\begin{tabular}{ll}
\hline Integrated services & 17
\end{tabular}

Intellectual Disability only 57

Intellectual Disability and other disabilities

Multiple disabilities

43

Source: Rao, LG, Reddy, S.H.K. Organizational aspects of special schools in Mental Retardation in India. International Journal of Rehabilitation Research, 2004; Vol.27, Issue 2

\section{Table III}

\section{VOCATIONAL TRAINING AND EMPLOYMENT}

Services of vocational phases

Per cent facilities

\begin{tabular}{ll} 
Prevocational & $90 \%$ \\
\hline Vocational Training & $87 \%$ \\
\hline On-the-job-Training & $59 \%$ \\
\hline Placement & $44 \%$ \\
\hline NGO with vocational facilities having all four phases & $34 \%$ \\
\hline Traditional Occupations & 27 (Nos.) \\
\hline Non-traditional Occupations & 55 (Nos.)
\end{tabular}

Source: Rao, L.G. and Siva Kumar, T.C. Re-engineering the vocational training of mental retardation. Journal of Community Guidance and Research, 2004; Vol.2I, No.I 


\section{National Institute for the Mentally Handicapped}

The National Institute for the Mentally Handicapped (NIMH) was established in 1984 as an autonomous organization of the Government of India at Secunderabad (Andhra Pradesh Province) has the mandate of developing state of the art service models, developing human resources and undertaking research and development in the area of intellectual disability in the country. Its quality policy is to excel in building capacities to empower persons with mental retardation through the departments of Adult Independent Living, Community Rehabilitation \& Project Management; Medical Sciences including Physiotherapy/Occupational Therapy/Speech Therapy, Rehabilitation Psychology and Special Education; and three Regional Centres at Kolkata, Mumbai and New Delhi. ${ }^{7}$

NIMH developed human resource development programmes keeping in mind life cycle needs, holistic development and the empowering environment for the ultimate quality of life of persons with intellectual disabilities. Presently NIMH conducts four diploma courses, two degree courses and five post graduate courses in Early Intervention, Early Childhood Special Education, Special Education, Vocational Rehabilitation, Rehabilitation Psychology, Community Based Rehabilitation and Disability Rehabilitation Administration. Until 31 ${ }^{\text {st }}$ March 2006, a total of 19773 professionals have been trained through the system. The Institute offers more than 50 professional development programmes as part of the continuing education for professionals working in voluntary and Government sectors. The Research and Development programmes were undertaken by the Institute and a few programmes have been completed in collaboration with international organizations. ${ }^{8}$

The Institute offers consultancy services to voluntary organizations. It has developed various service models based on the research, which include home based, community based, parent training programmes, early intervention services, special education services, vocational models etc. Efforts in the provision and outreach programmes usually help the local capacities to emerge for establishing the services in the community. More than two hundred thousand persons with disabilities were identified and provided services.

\section{Parent cooperatives}

Currently there are nearly 200 parent associations in the country with a membership of over 40000 parents. Under the guidance of NIMH, a National Federation called PARIVAAR functions as a central organ for all the parent associations that provide constant and regular support to the families. Services include emotional support, information about the condition and referral resources, information about government schemes, organizing conferences for parents to elicit the needs and difficulties to be placed before the government. PARIVAAR with the support of NIMH has been organizing National Parent Meets for the past 14 years. Starting this year, Regional Parent Meets are also being organized. Matters concerning support to individuals and families, public policy, technology, self-help groups, etc. are discussed for taking to the Government and other appropriate agencies. These meets also create public awareness, undertake programmes for community support and contribute to public policies.

\section{Community based rehabilitation}

Since its movement in the 1970 's, community based rehabilitation (CBR) has become considered as a viable and sustainable new entry point aiming at improvement of the quality of life of disabled persons. It should be made available within rural as well as urban communities, as highly specialized institutions away from the mainstream and with the traditional system of urban centred special settings have not been able to reach the rural people. Further, this approach has not fully adapted to the physical, economic, social and cultural needs and link to the availability of local resources and views of the stakeholders in the villages.

The CBR project at Byrraju Foundation is establishing community services with linkages after identifying the community needs in 182 villages adopted by the foundation. This is a bottom-up approach with PWD, family, and community as the centre. Children with mild and moderate category of disability can be admitted in the regular classes with the class teacher as a resource with adequate orientation. Other options are engaging itinerant teachers, creating resource rooms in regular classes, and arranging special classes in regular schools for children with intellectual disabilities. It may be observed from the described model that a greater number of children with intellectual disabilities will benefit from a less restricted learning environment, which is directly proportionate to a lower severity of retardation. The above model is gaining momentum with many NGOs organizing CBR programs in the country, mostly with the support of government. Byrraju Foundation has taken an innovative initiative of developing resources in the communities, so that the rehabilitation services are mostly available for the people, by the people and of the people in the same community with due networking with resource organizations. 


\section{Action Plan of the Government of India}

The Government of India is implementing an action plan to make mainstream education not just available but accessible, affordable and appropriate for students with disabilities. Quality of education for these children is also a concern of the action plan. The action plan will cover the following levels of educational interventions.

- Integrated child development service programmes for children in the age group of 0 to 6 years.

- A national rural health mission will cover early identification and intervention of children at risk.

- Sarva Shiksha Abhiyan for children in the age group of 6 to 14 years.

- A revised plan for Inclusive Education of Children and Youth with Disabilities (IECYD) will include persons with disabilities in the age range of 14 to 18 years.

In keeping with the action plan, all the schools in the country will be made disabled friendly by 2020 and all educational institutions including hostels, libraries, laboratories and buildings will have barrier free access for the disabled. There are many positive and promoting features to make inclusive education a success.

\section{National Policy}

As per the National Policy, the Government of India envisages that every child with disability has access to appropriate preschool, primary and secondary level education by 2020 . Special care will be taken to:

i. Make schools (building, approaches, toilets, playgrounds, laboratories, libraries etc.) barrier free and accessible for all types of disability.

ii. The medium and method of teaching will be suitably adapted to the requirements of most disability conditions.

iii. A technical/supplementary/ specialized system of teaching/learning will be made available within the school or at a common centre easily accessible to a cluster of schools.

iv. Teaching/learning tools and aids such as educational toys, Braille/talking books, appropriate software etc. will be made available. Incentives will be given to expand facilities for setting up of general libraries, e-libraries, Braille libraries, talking book libraries, resource rooms etc.

v. National Open School and distance learning programmes will be promoted and extended to other parts of the country. vi. Sign language, Alternative and Augmentative Communications (AAC) and other modes as a viable medium in inter personal communication will be recognized, standardized and promoted.

vii. Schools will be made geographically more accessible. Alternatively, viable travel arrangements will be made with the assistance of the community, State and NGOs.

viii. Parent-Teacher counselling and a grievance redressal system will be set up in the schools.

ix. There will be a separate mechanism to review annually the intake and retention of the girls with disabilities at primary, secondary and higher education levels.

$x$. Many children with disabilities, who cannot join the inclusive education system, would continue to get educational services from special schools. Special schools shall be appropriately re-modelled and re-oriented based on technological development. These schools will also help prepare children with disabilities to join mainstream inclusive education.

xi. In some cases due to the nature of disability (its type and degree), personal circumstances and preferences, home-based education will be provided.

xii. Course curriculum and the evaluation system for children with various disabilities shall be developed keeping in view their capabilities. The examination system will be modified to make it disabled friendly by exemptions such as learning mathematics, learning only one language, etc. Further, facilities like extra time, use of calculators, use of Clarke's tables, scribes, etc. would be provided based on the requirement.

xiii. Model Schools of Inclusive Education will be set up in each State/ Union Territory to promote education of persons with disabilities.

xiv. In the era of the knowledge society, computers play a very important role. Efforts will be made so that every child with disability is suitably exposed to the use of computers.

xv. Children up to six years of age with disabilities will be identified and necessary interventions made so that they can become capable of joining inclusive education.

xvi. Educational facilities will be provided in psychosocial rehabilitation centres for mentally ill persons.

xvii. Many schools discourage enrolment of students on account of their disability due to lack of awareness about the capabilities of disabled persons. Programmes will be implemented for sensitization 
of teachers, principals and other staff members in all schools.

xviii. Special Schools presently being supported by the Ministry of Social Justice \& Empowerment will incrementally become resource centres for inclusive education. The Ministry of Human Resource Development shall open new special schools depending upon the requirement.

xix. Adult learning/ leisure centres for adults with severe learning difficulties will be promoted.

$x x$. Three percent reservation for persons with disabilities in admission to higher educational institutions will be enforced. Universities, colleges and professional institutions will be provided financial support to establish a Disability Centre to take care of educational needs of students with disabilities. They will also be encouraged to make classrooms, hostels, cafeterias and other facilities in the campus accessible to students with disabilities.

xxi. Include a module in induction and in-service training programmes for teachers on issues relating to management of children with disabilities. ${ }^{9}$

\section{Conclusions}

With the ratification of the UN Convention on the Rights of Persons with Disabilities on $1^{\text {st }}$ October 2007 by the Government of India, it is expected that the National Policy that has extensively covered the education of persons with disabilities will be able to realize the goals of Biwako Millennium Framework. National Policy has also considered as crucial the development of human resources for providing education to all children with disabilities in the general education stream. Many milestones have been left behind in the path, significant achievements have been made and opportunities have been created for the disabled. Much has been done but much remains to be done. In sum -the new millennium may signify many things to many people but what it should signify to all is that in terms of disability rehabilitation, new and emerging perspectives in special education cannot be ignored.

\section{References}

I. Persons with Disabilities (Equal Opportunities, Protection of Rights and Full Participation) Act, 1995.

2. National Trust for the Welfare of Persons with Autism, Cerebral Palsy, Mental Retardation and Multiple Disabilities Act, 1999.

3. Census of India 200I, Government of India, New Delhi.

4. Rao LG, Reddy SHK. Organizational aspects of special schools in Mental Retardation in India. International Journal of Rehabilitation Research, 2004; Vol.27, Issue 2.

5. Rao LG, Siva Kumar TC. Re-engineering the vocational training of mental retardation. Journal of Community Guidance and Research, 2004;Vol.2I, No.I.

6. Rehabilitation Council of India Act, 1992, Government of India, New Delhi.

7. Rao LG, Narayan J, Mani MNG. Status of education of children with disabilities. Secunderabad: National Institute for the Mentally Handicapped, 2005.

8. Rao LG (Ed). Perspectives on Special Education Neelkamal Publications Pvt. Ltd, Hyderabad, India, 2007.

9. National Policy for Persons with Disabilities, Government of India., 2006. 